\title{
Hormonal receptors in mammary carcinoma: comparison between quantitative and qualitative methods
}

\author{
Fundação Oncocentro de São Paulo. Breast Clinic at Hospital Alemão Oswaldo Cruz - São Paulo, Brazil
}

\begin{abstract}
Alternatives to the traditional hormone receptor dosages for prognostic evaluation and clinical approach to breast cancer have been proposed for immunohistochemical determinations. For correlation purposes, such procedures were compared in 37 patients presenting 5 to 15 years of survival. Considering $30 \mathrm{fm} / \mathrm{mg}$ as the positivity index, the disagreement between both methods reached $35.1 \%$ with estrogen and $48.5 \%$ with progesterone receptors. When the positiveness level was changed to $20 \mathrm{fm} / \mathrm{mg}$, the discrepancies were reduced to $32 \%$ with ER and increased to $57 \%$ with $\mathrm{PgR}$. This study leads us to not recommend the immunohistochemical method applied to paraffin sections as an alternative procedure to the dextran-charcoal dosage for prognosis and therapeutic management of mammary carcinoma.
\end{abstract}

UNITERMS: Breast carcinoma. Prognosis. Hormonal receptors assays. Correlation of methods.

\section{INTRODUCTION}

$\mathrm{T}$ The hormonal dependence of breast cancer has been known and discussed for over 100 years. In 1889, Schinzinger' in Germany, was the first to call attention to this fact and Beatson ${ }^{2}$ in Scotland, in 1896, presented a paper showing cases of mammary carcinoma remissions after bilateral oophorectomy. However his results did not exceed $30 \%$ of patients. After the laboratory isolation of cortisone, hormonal ablative surgery to control mammary cancer has been extended to also include adrenalectomy and hypophysectomy.

Meanwhile, endocrine additive treatments were started and successively estrogens, androgens,

\section{Address for correspondence:}

Antonio Franco Montoro

Praça Amadeu Amaral, 47

São Paulo/SP - Brasil - CEP 01327-010 progesterone, anti-hormones like tamoxifen, aromatase inhibitors, and recently LH-RH analogs, were used in order to control breast cancer.

All these attempts had in common one question: to what percentage would the patients respond to this hormone manipulation? Without a selective criterion the results were similar to those shown by Beatson, ie only one third were responsive.

By 1970 there were clinical and biochemical parameters to predict therapeutic results that would allow the drawing of conclusions regarding different grades of hormonal dependence. Among them, the disease-free interval proved to be worthwhile. When the time elapsed between the curative mastectomy and the first recurrence of disease was longer than five years, the responsiveness rate to endocrine manipulation increased to two thirds of the patients.

In the early seventies, Jensen ${ }^{3}$ identified the estrogen receptor (ER) in the mammary tumor cell as a reliable parameter to evaluate the grade of hormone dependence right at the beginning of treatment, without having to wait for five years of evolution. 
Jensen believed that the mammary carcinoma hormonal dependence was positive when the biochemical dosages indicated a receptor amount above three fentomoles/milligram of neoplastic tissue. Lately, another estrogenic derived marker has been identified, the progesterone receptor $(\mathrm{PgR})$. Its positivity index was initially placed at five $\mathrm{fm} / \mathrm{mg}$ of tissue ${ }^{4}$

With further research progress it became evident that the index of 3 or $5 \mathrm{fm} / \mathrm{mg}$ was too low to characterize the degree of hormone dependence of the neoplastic tissue 5 . This index was gradually elevated to 10,20 and $30 \mathrm{fm} / \mathrm{mg}$. Even Jensen ${ }^{6}$, as his own experience increased, came to the conclusion that $50 \mathrm{fm} / \mathrm{mg}$ would be the ideal index to make a correct prognostic evaluation and prediction of therapeutic response to the endocrine treatment.

Meanwhile, in addition to quantitative methods for receptor dosages, immunohistologic qualitative techniques were developed following the pioneer research started by Pertschuk ${ }^{7}$. When the tumor receptor content was not established during surgery, such information could possibly be determined through paraffin sections. Thus, the hormonal dependence of breast cancer pointed out by the receptor presence, in both estrogen and progesterone conditions, being positive or negative, could represent an alternative approach to improve the mammary carcinoma management.

In this study, we present the results of quantitative biochemical dosages of hormonal receptors in frozen tumor tissue and qualitative immunohistochemical analyses in paraffin sections carried out on the same group of patients.

\section{MATERIAL AND METHODS}

Out of a series of 100 women treated for mammary carcinoma with an asymptomatic survival of 5 to 15 years, with receptor dosages for estrogen and progesterone (Dextran-Charcoal method) and with the immunohistochemical determinations of estrogen and progesterone antibodies (P29 Biogenex), we selected 37 patients presenting reliable paraffin sections.

This group varied in age from 30 to 72 years old; the clinical stages were: CS 0: 1; CS I:9; CS II: 21 ; CS III: 6 cases. Axillary lymphonode metastases were present in 18 and absent in 19 patients.

The hormonal receptor values ranged from zero to $762 \mathrm{fm} / \mathrm{mg}$ for ER, and from zero to $1,629 \mathrm{fm} / \mathrm{mg}$ for $\mathrm{PgR}$. The positiveness value was set at $30 \mathrm{fm} / \mathrm{mg}$. For qualitative determinations, the results were considered as positive or negative for both conditions.
The median survival rate of this series reached 105.5 months. It was analyzed for prognostic purposes and correlated to the clinical stage of disease as well with the axillary status and its receptor positiveness, according to both quantitative and qualitative procedures. In clinical stage zero with non palpable tumor the survival rate was 120 months. When the axilla was negative 113.7 months. In receptor positive above $30 \mathrm{fm} / \mathrm{mg}$ it was 112.7 , and only 109.4 months for the patient presenting qualitative positive results.

The comparison between the two methods is shown in Tables 1 and 2. The concordance rate for ER was $64.8 \%$ and for $\mathrm{PgR} 51 \%$. Considering that numerous authors accept 20 $\mathrm{fm} / \mathrm{mg}$ as positive for both hormone receptors, we also used this index. As a result, the estrogen receptor showed a reduction of discrepancy from 35.1 to $32 \%$. For the progesterone receptor there was a discrepancy increase to $57 \%$.

\section{DISCUSSION}

Jensen $^{3}$ noticed that the longer survival and better response rates to hormonal manipulation were directly proportional to quantitative receptor levels. The higher the index the greater the benefit. Similarly, adrenalectomy and

Table 1

Correlation with ER results. The qualitative determinations disagreed by $35.1 \%$ with the quantitative dosages

\begin{tabular}{|c|c|c|c|c|c|}
\hline Method & $\#$ & $\%$ & Method & \# & $\%$ \\
\hline C & $4 / 2$ & 70. & $\mathrm{DC}+\mathrm{IH}$ & $6 / 20$ & 30.0 \\
\hline C- & $10 /$ & 58. & DC- $\quad \mathrm{IH}+$ & $7 / 17$ & 41.1 \\
\hline Concordance & $24 / 37$ & 64.8 & Discrepancy & $13 / 37$ & 35.1 \\
\hline
\end{tabular}

DC: Dextran charcoal dosage

IH: Immunohistochemical assay

Table 2

Correlation with PgR results. For this condition the disagreement reached $\mathbf{4 8 . 5 \%}$

\begin{tabular}{|c|c|c|c|c|c|}
\hline Method & \# & $\%$ & Method\# & $\%$ & \\
\hline DC. & $3 / 18$ & 16.6 & $\mathrm{DC}+$ & $15 / 18$ & 83.3 \\
\hline DC- IH - & $15 / 17$ & 88,2 & $\mathrm{DC}-\mathrm{IH}+$ & $2 / 17$ & 11.7 \\
\hline Concordance & $18 / 35$ & 51.0 & Discrepancy & $17 / 35$ & 48.5 \\
\hline
\end{tabular}

DC: Dextran charcoal dosage

$\mathrm{IH}$ : Immunohistochemical assay 
castration procedures exhibit increased responses when compared to endocrine additive therapies.

After the introduction of the $\mathrm{PgR}$ condition as another marker for breast cancer hormonal dependence evaluation, such observations were confirmed ${ }^{4.8}$, especially by Osborne ${ }^{9}$, who demonstrated that the progesterone receptor was more sensitive than ER as a prognostic marker, because its value is independent of the pre or post menopausal status, while the ER condition shows up only after the menopause.

The literature on the comparison between the quantitative and qualitative methods has shown discordant results ${ }^{10-12}$. Janssens et $\mathrm{al}^{13}$ concluded that histochemistry determinations and the biochemical dosages were not concordant when the latter were considered positive at 10 $\mathrm{fm} / \mathrm{mg}$ of tissue. On the other hand, Pertschuk et $\mathrm{al}^{14}$ utilizing the same index of $10 \mathrm{fm} / \mathrm{mg}$ found a $80 \%$ concordance between both methods. The authors used only estrogen receptors and the immunohistochemistry test was performed on frozen biopsy tissue. Leal et $\mathrm{al}^{15}$ using identical methods found $92 \%$ in agreement. Panko et al ${ }^{16}$ however, found a concordance of $63 \%$ and came to the conclusion that the selection of patients for endocrine therapy should not be made on the basis of immunohistochemistry methods.

The diversity of opinions and conclusions about comparative studies was explained by Osborne ${ }^{17}$. This author assigned these conflicting results, especially in relation to the estrogen receptors, to the tumor heterogeneity, where hormone responsive and nonresponsive cells were present in variable proportions. For Osborne, these varying fractions were responsible for the $15 \%$ to $34 \%$ non-concordance of his results. He added that the clinical responses related to immunohistochemistry were non-satisfactory in $40 \%$ of his patients. Borjesson et $\mathrm{al}^{18}$ came to the same conclusion. Thorpe et $\mathrm{al}^{19}$ found that the uniformization of the techniques of citosol preparation contributed to the reduction of the differences seen in the dosages performed by several laboratories, especially concerning the progesterone receptors.

Ozello et $\mathrm{al}^{20}$ confronted the quantitative method with immunohistochemistry executed in frozen tissues, imprints and paraffin block sections. Except for the latter, the results between the two methods were concordant.

It must be said that one reason for disagreement between quantitative and qualitative methods using frozen sections is the low index criterion for positiveness. Parl and Posey ${ }^{21}$ verified $89 \%$ in concordance when the index for receptors was taken at 3 fentomoles. Kinsel et $\mathrm{al}^{22}$ using 10 $\mathrm{fm} / \mathrm{mg}$ as parameter found the agreement just below $70 \%$.

Finally, Hasson et $\mathrm{al}^{23}$ stressed that the material to be submitted either to quantitative or qualitative methods should be taken early from the biopsy fragment and not from the surgical specimen. Besides, a further measure to reduce the discrepancies is that the tissue should be taken from different areas of the tumor. This precaution applies to either the quantitative or the qualitative determinations.

\section{CONCLUSIONS}

Our study of correlation between the quantitative method with dextran charcoal technique for ER and PgR and the qualitative immunohistochemical procedure using antibodies antireceptors for estrogen and progesterone on paraffin sections, reached the conclusion that the concordance between the two methods is not satisfactory. Thus, we do not recommend the immunohistochemical determination applied to paraffin sections as an alternative to the quantitative procedure for the prognostic evaluation of mammary carcinoma.

\section{Resumo}

A tradicional dosagem dos receptores hormonais para avaliação prognóstica e abordagem clínica no câncer de mama, métodos alternativos para determinação imunohistoquímica vêm sendo propostos. Com finalidade comparativa, tais procedimentos foram correlacionados em 37 pacientes exibindo 5 a 15 anos de sobrevida. Tomando como indice de positividade $30 \mathrm{fm} / \mathrm{mg}$ a discordância entre os métodos alcançou $35,1 \%$ com os estrógenos e $48,5 \%$ com os receptores de progesterona. Quando o nivel de positividade foi alterado para $20 \mathrm{fm} / \mathrm{mg}$ o desencontro de resultados reduziu-se para $32 \%$ com o ER, elevando-se para $57 \%$ com o PgR. Este estudo nos permitiu concluir pela não recomendação do método imunohistoquímico com laminas fixadas em parafina, como um procedimento alternativo à dosagem com carvão-dextrã, para prognóstico e abordagem terapêutica no carcinoma mamário. 


\section{REFERENCES}

1. Schinzinger: Chir Congress 1:28-29,1889 In: Juret P. Endocrine surgery in human cancers. Springfield. CR Thomas Publisher. 1966:7

2. Beatson GT: On treatment of operable cases in carcinoma of mamma: suggestion for a new method of treatment with illustrative cases. Lancet 1896;2:104-7

3. Jensen EV: Estrogen receptors in hormone-dependent breast cancers. Cancer Res 1975;35:3362-4

4. McGuire WL: Value of steroid receptors assays in the management of patients with breast cancer. Breast 1978;4:3-6

5. Montoro AF: A importancia clinica dos receptores hormonais no carcinoma mamario. Rev Bras Ginec Obstet 1981;3:20-5

6. Jensen EV: Personal communication

7. Pertschuk LP:Tobin EH et al: Immunofluorescent detection of estrogen receptors in breast cancer. Cancer 1978; 41:907-11

8. Montoro AF; Rivera JS \& Montoro FF: Receptores hormonais e manipulação endócrina. Femina 1993;21:816-25

9. Osborne CK: Receptors. In: Harvis JR,Helmann S,Henderson IC \& Kinne DW. Breast Diseases. Philadelphia: JBLippincott Co 1991:301

10. King WJ;De Sombre ER; Jensen EV \& Greene GL: Comparison of Immunocyto-chemical and steroid-binding assays for estrogen receptor in human breast tumors. Cancer Res 1985;45:293-304

11. Miller RT;Hapke MR \& Greene GL: Immunocytochemical assay for estrogen receptor with monoclonal antibody D753P routinely processed formaldehyde fixed breast tissue. Cancer 1993;71:3541-6

12. Sklarew RJ; Bodmer SC \& Pertschuk LP: Quantitative imaging of immunocyto-chemical estrogen receptor staining patterns in breast cancer sections. Cytometry 1990;11:359-78

13. anssens JP; Pylyser K et al: Biochemical and histochemical analysis of steroid hormone binding sites in human primary breast cancer. Cancer 1985;55:2600-11
14. Pertschuk LP; Eisemberg KB; Carter AC \& Feldmann JG: Immunohistologic localization of estrogen receptors in breast cancer with monoclonal antibodies. Correlation with biochemistry and clinical endocrine response. Cancer 1985;55:1513-8

15. Leal SN;Rosen L; Frank B \& Poppiti Jr RJ: Comparison of estrogen receptor determination using the estrogen receptor immunocytochemical assay in 85 human breast carcinomas. Breast Dis 1989;1:243-51

16. Panko WB; Mattioli CA \& Wheeler TM: Lack of correlation of a histochemical method of estrogen receptor analysis with biochemical assay results. Cancer 1982; 49:2148-52

17. Osborne CK: Heterogeneity in hormone receptor status in primary and metastatic breast cancer. Seminars in Oncology $1985 ; 12: 317-26$

18. Borjesson BW; Canchi MN et al: Sources of improvement between laboratory variation in estrogen and progestin receptor measurements using samples during the Australasian quality assurance programme. Eur J Cancer Clin Oncol 1989; 25:1087-93

19. Thorpe SM; Poulsen HS; Pederson KO \& Rose C: Impact of standardization of estrogen and progesterone receptors assays of breast cancer biopsies in Denmark. Eur J Cancer Clin Oncol 1988:24:1263-9

20. Ozzello L; De Rosa C; Habif DV \& Greene GL: An immunohistochemical evaluation of progesterone receptor in frozen section, paraffin sections and cytologic imprints of breast carcinomas. Cancer 1991; 67:455-62

21. Parl FF \& Posey YF: Discrepancies of the biochemical and immunohistochemical estrogen receptors assays in breast cancer. Human Pathol 1988:19:960-6

22. Kinsel B; Szabo E et al: Immunocytochemical analysis of estrogen receptors as a predictor of prognosis in breast cancer patients: comparison with quantitative bio-chemical methods. Cancer Res 1989;49:1052-6 